\title{
The Relationship between Ranau Krui and Retta
}

\author{
Darsita Suparno \\ Translation Department Faculty of Adab and Humanities \\ Syarif Hidayatullah State Islamic University Jakarta, Indonesia \\ darsitasuparno@uinjkt.ac.id
}

\begin{abstract}
This research examines the historical relationship between Ranau, Krui and Retta languages. As they are all members of the Austronesian language family, those languages have similarities and differences in their lexical or phonological features. The aims of this study are: (1) to describe synchronically the phonological system of Ranau, Krui and Retta, (2) to describe the reflexes of Proto Malayo-Polynesian phonemes which have either retention or innovation that occur in Ranau, Krui and Retta, and (3) to describe the historical relationship between Ranau, Krui and Retta by observing the sound correspondence that can prove the existence of kinship relationship between the three languages. The data used in this research are secondary data drawn from the collection of data in the previous study for Ranau and Krui, and primary data especially in the Retta language from it $s$ native speakers. This research was conducted with the method and framework of diachronic linguistics theory that applies quantitative and qualitative approaches. Both methods were used to find evidence to explain the historical relationship between the three languages being studied. Based on lexicostatistical technique, it is known that the average cognate percentage of the Ranau, Krui, and Retta languages is $46 \%$. This proves that the relationship between the three languages make them members of the same subfamily language of MalayoPolynesian branch. A number of findings that explain the characteristics of those languages in sporadic or secondary rules include lenition (sound attenuation), apheresis, apocope, and syncope.
\end{abstract}

Keywords: reflex of phoneme, primary, secondary rule, lexicostatistic, reconstruction technique, innovation, retention

\section{INTRODUCTION}

Language is the source of human life and power, Fromkin [1, p. 1] Human languages are systems that tie together different aspects of reality into a naturally founded socially and culturally functioning communication system. As a tool for communication, a language conveys ideas, thought to others. According to Crystal [2, pp. 3-4], the number of languages in the world is estimated at less than 6,000 languages. This study would like to understand in a specific sense perceived meaningful relations between Ranau, Krui and Retta languages in Indonesia. These three languages are sub-categorized into two different language families, i.e. Austronesian or MalayoPolynesian and Non-Austronesia.

Ranau and Krui in Sumatra are classified as members of Malayo-Polynesian Arka [3, p. 3], while Retta is subcategorized as a non-Austronesian language Schaper, [4, p. 149]. As the objects of this study, Ranau, Krui and Retta are the primary languages spoken by their native speakers in daily exchanges. The Ranau people live near lake Ranau in several villages in South Sumatra, Ogan Komering Ulu Regency, and at Banding Agung subdistrict, namely Pilla and Warkuk. On the other hand, the Krui live near Lampung bay east coast at Pahmongan, Labuan Mandi, and Gunung Kemala villages. The Ranau and Krui languages are classified as the members of Austronesian language family from the Western MalayoPolynesian branch Hidayah [5, p. 192].

The Retta language, on the other hand, is spoken by the people of South Ternate village, in Kalabahi Bay, South Ternate Island. This language is included in the Trans-New Guinea language family Klamer, [6, p. 39]. Retta is one of the Alor-Pantar family constituting a group of twenty Papuan languages spoken on the island of Alor and Pantar, located just north of Timor at the end of Sunda island chain, roughly the island east of Bali and west of New Guinea. This outlier "Papuan" group is located 1000 kilometers west of the New Guinea mainland. The term Papuan is used here as a cover term for the hundreds of languages spoken in New Guinea and its vicinity that are not Austronesia Ross, [7, p. 15]. People in two non Blaggar villages on Pura with some 10.000 inhabitants are Retta speaking people, a related but nevertheless distinct language. All Retta speakers are minority in their community Schapper, [4, p. 149].

Historically, Sriwijaya kingdom in the 7th - 12th century AD had a wide influence in various fields such as education, social, political, and trade from South Sumatra to Mataram, Majapahit, Banten, Pagaruyung, and Lampung. Lampung tribe is the origin of Ranau. A war between tribes caused them to move from Lampung to Lake Ranau in the 15th century. Since then those people settled in the area around the lake and identified themselves as Ranau people. At present, they are identified as the Ranau people who live near Lake Ranau in South Sumatra. The Ranau live in a few villages in South Ogan Komering Ulu Regency, in Banding Agung sub district. Linguistically, the Ranau speak a dialect of the Lampung Api language. They are able to understand the Komering, Daya, Krui and some other related languages. Ethnically, however, they are identified as Lampung Pesisir people not as Daya or Komering people. Some Ranau people are also able to speak the Palembang trade language well.

Based on the above explanation, it can be summarized that: Firstly, in Indonesia, there are two groups of languages that live together, namely: the Austronesian languages and a family of languages outside Austronesian, which is called by SIL [8] as groups of Trans-New Guinea languages. In this paper, 
languages outside the Austronesian group are termed as the group of non-Austronesian languages. Secondly, the grouping of languages is based solely on the similarity of the characteristics of each language (surface structure). Therefore, study about many languages in Sumatra and East Nusa Tenggara is important, especially in the case of studying the endangered languages.

The problems to be discussed in this paper are:

a. How are the phonological systems of Ranau, Krui, and Retta synchronously?

b. How to describe the reflexes Proto Malayo-Polynesian phonemes in Ranau, Krui, and Retta reflex phonemes of proto Trans-New Guinea?

c. How to find evidence of kinship in the form of renewal (innovation) that shows the closeness of the historical relationship between the languages diachronically?

d. How is the relationship between kinship language by comparing cognate words with lexicostatistics technique and reconstruction technique in order to know the percentage of kinship that can explain the rank of kinship quantitatively and qualitatively?

\section{METHOD}

The population of this study are the Ranau, Krui, and Retta. There are two research materials, namely primary data and secondary data. For data of Retta language, this research uses secondary data from Kurniawati's work [9, pp. 905906]. For Ranau and Krui Language were taken from interviews native speakers, such as: Ranau language was obtained from speakers in Pilla and Warkuk villages, while Krui language was obtained from interview with the speakers of the language in Pahmongan village. Acording to Sudaryanto [10, p. 26] method is a way of working whice must be described in appropriate for the tools and characteristic of those are used. The use of appropriate methods of its tool is called a technique. Thus, one can recognize the method only through its techniques. The method used in this study includes three strategic stages as stated by Sudaryanto [11, p. 5], namely: a) method of providing data, b) methods of data analysis, and c) method of presenting the result of data analysis.

\section{A. Data Collection}

Data for this study were collected in two ways, namely collecting primary data and secondary data. The primary data were obtained directly from the informants using a questionnaire containing a list of vocabulary. In this context, the data were collected by using an instrument in the form of Swadesh 200 list of basic vocabulary. The data were then completed in a number of utterances in the form of basic vocabulary in the sentence in order to use the calculation of lexicostatistics and reconstruction techniques. Data on Retta language that serves as the secondary data of this research were collected using non-interactive techniques. These techniques include: library study, observation, and records study.

\section{B. Data Analysis}

For synchronous studies, the data were analyzed and described according to the reality of the speech community. For diachronic studies, data were analyzed by establishing qualitative and quantitative comparative methods. Quantitative methods were intended to record cognate words based on similarities that were not caused by the borrowing factor. The method was performed by the lexicostatistics technique. The lexicostatistic technique is one of the historical or diachronic analyzes used to distinguish a dialect from a language.

In this study, lexicostatistic techniques were used to determine the relationship of Ranau, Krui, and Retta languages. The aim of using qu a n t it at ive methods was to find the kinship line between the languages being studied. Explanations to the findings are provided by applying a qualitative comparative method namely: a method instrument of more than 200 basic vocabularies. The technique used was a top-down reconstruction from the highest rank to modern language. Determination of proto-language is a high-tech language tool. Furthermore, Ranau, Krui, and Retta are considered as modern languages. Through this step is obtained a basic of lexical items which are retention and innovation.

\section{RESULT AND DISCUSSION}

Diachronic discussion of Ranau, Krui and Retta languages started from the synchronous aspect. The forms of Ranau, Krui, and Retta languages are discusses based on: a) lexical reconstruction to explain cultural, historical, social; b) phonological reconstruction to know the regular primary sound changes that can give an indication of the relationship between them. Schapper [4] classifies Retta as a Trans-New Guinea language, West-Alor Pantar. The languages in this region are divided into three language variants: Blaggar, Alor, and Pantar, Simons and Fennig, [8]. On the other hand, Wurm and Hattori classify Ranau and Krui as Austronesian specifically, MalayoPolynesian, or Lampungic Coastal. Here are some examples of the three vocabularies of those languages.

TABLE 1

EXAMPLES OF VOCABULARY DIFFERENCES IN THE THREE LANGUAGES

\begin{tabular}{|c|c|c|c|c|}
\hline $\begin{array}{c}\text { Language } \\
\text { area }\end{array}$ & $\begin{array}{l}\text { Warkuk } \\
\text { village }\end{array}$ & $\begin{array}{c}\text { Pahmongan } \\
\text { village }\end{array}$ & $\begin{array}{l}\text { Umapara } \\
\text { Village }\end{array}$ & Gloss \\
\hline Isolect & Ranau & Krui & Retta & \\
\hline 1 & [tahlan] & [telan] & [tal:a] & /bone/ \\
\hline 2 & [kajon] & [ingom] & [pinamiG] & /husband/ \\
\hline 3 & [debini] & [bini] & [kak:ua] & /night/ \\
\hline 4 & [kamaq] & [makama] & [kar:ita] & /dirty/ \\
\hline 5 & [langui] & [layui; & [val:a] & /to swim/ \\
\hline 6 & [kiang] & [nyayuk] & [tat:i] & /dry/ \\
\hline 7 & [tigusuk & [pusau]] & [ko:sog] & /to rub/ \\
\hline 8 & [yekui] & [kekui] & [gat:u] & /to scratch/ \\
\hline 9 & [kantiq] & [jama] & [oli] & /with/ \\
\hline 10 & [tijujun] & [jujuh] & [gar:umba] & /to push/ \\
\hline
\end{tabular}

Source: Kurniawati [9]; Abdullah and Darsita [12]; Arifin [13] 
The following vocabularies present some observable sound changes in the three languages.

\section{TABLE 2}

SOUND CHANGES IN THE THREE LANGUAGES

\begin{tabular}{|c|c|c|c|c|}
\hline $\begin{array}{c}\text { Language } \\
\text { area }\end{array}$ & Warkuk & Pahmongan & Umapara & Gloss \\
\hline Isolect & Ranau & Krui & Retta & \\
\hline 1 & [way] & [wai] & [jail; ai] & /water/ \\
\hline 2 & [bakaq] & [baka] & [bari:kiG] & /root/ \\
\hline 3 & [balik] & [balik] & [balek ] & /behind \\
\hline 4 & [biji, & [biji] & [bijiG] & /seed/ \\
\hline 5 & [lapah] & [lapah] & [lapa:al] & /to \\
\hline 6 & [balak] & [balak] & [bal] & / big/ \\
\hline 7 & [binatan] & [binatay] & [binanta] & /animal \\
\hline 8 & [buya] & [buya] & [bu:ma] & /flower/ \\
\hline 9 & [hapus] & [hapus] & [hap:o] & /to \\
\hline 10 & [cutik] & [cutik] & [kudik] & /lack/ \\
\hline
\end{tabular}

Source: Kurniawati [9]; Darsita and Abdullah [12]; Arifin [13]

In relation to sound-change, in comparative linguistic studies, Crowley [14, pp. 38-57] mentions the types of sound changes namely: lenition, sound addition, sound deletion, metathesis, fusion and assimilation. Lenition is a kind of consonant mutation that arises in the form of weakening of a voiced consonant into a soundless consonant. The diachronic analysis uses phonemic correspondence with secondary rules of innovation techniques. To see phonemic correspondence phenomenon the researcher used English Finderlist of Reconstruction in Austronesian Languages (Post Brandstetter) by S.A. Wurm and B. Wilson. The findings are as follow:

A. Apheresis (the deletion of sound at the beginning of a word) The vocabulary in Ranau and Krui way or wai 'water' sounds semivocal * / w / changes in Retta. The change can be defined as follows $* / \mathrm{w} />\theta$.

$$
\begin{array}{cccc}
*_{\text {wai }} & > & \text { ai; way } & \text { 'water' } \\
*_{\text {canu }} & > & \text { an:u } & \text { 'one' }
\end{array}
$$

B. Syncope (the removal of phonemes in the middle of a word) The word kanan in Ranau and Krui means 'right'; voiced labiodental sound /v/ disappears in Retta. The change can be formulated as follows $* / \mathrm{v} />\mathrm{t}$. While in Ranau language changes $* / \mathrm{v} />\mathrm{k}$. In Ranau, Krui and Retta are found that syncope processes of phoneme namely: */v/, */y/, and */b/

$\begin{array}{llll}\text { *vanan } & > & \text { tan:e } & \text { 'right' } \\ & & \text { kanan } & \\ \text { *buya } & > & \text { buma } & \text { 'flower' }\end{array}$

\section{Apocope (omission at the end of a syllable)}

The data shows some kinds of consonant sound disappearance at the end of the word like: * mantaq $>$ manta 'crude'. The vocabulary in Ranau and Krui the word anak 'child' nasal /n/ disappearance and become $* / \mathrm{v} /$ in Retta. The change can be defined as follows $* / \mathrm{n} />\mathrm{v}$. In Ranau, Krui and Retta are found apocope phonemes $* / \mathrm{n} /, * / \mathrm{k} /$, and $* / \mathrm{q} /$

$\begin{array}{cccc}* \text { api } & > & \text { ad } & \text { 'fire' } \\ * \text { balik } & > & \text { bale } & \text { 'behind' } \\ * \text { anak } & > & \text { val } & \text { 'child' } \\ \text { *besar } & > & \text { bal } & \text { 'big' } \\ \text { *qapus } & > & \text { hapus } & \text { 'to erase' } \\ & & \text { hapo } & \end{array}$

D. Prothesis (a process of sound change by adding a phoneme)

This change is usually done by adding a phoneme at the beginning of the word Keraf [15, p. 91]. The vocabulary in Ranau and Krui languages the word nyaku 'I' nasal sound $* / \tilde{n} /$ has changed in Retta to / $\mathrm{n} /$. The change can be formulated such as follows

* / a / / $\tilde{\mathrm{n}}$ / ; * / b / become / t / in Ranau and Krui languages. These facts can be found in the following:

$\begin{array}{cccc}* \text { aku } & > & \text { ñaku } & \text { 'I' } \\ * \text { itu } & > & \text { heno } & \text { 'that' } \\ & > & \text { seno } & \\ \text { *hitem } & > & \text { aGa } & \\ & & \text { halom } & \text { 'black' } \\ \text { *binatang } & > & \text { binanta } & \\ & & & \text { 'animal' }\end{array}$

E. Epenthesis (the insertion of sounds in the middle of a word)

This can be seen in the following data:

$\begin{array}{cccc}* \text { ia } & > & \text { izi } & \text { 'dia' } \\ & > & \text { idi } & \\ \text { *daun } & > & \text { ravina } & \text { 'leaf' } \\ & & \text { bulun } & \\ \text { *kanan } & > & \text { havanana } & \text { 'kanan' } \\ \text { *tulay } & > & \text { tahlan } & \text { 'bone' } \\ & > & \text { telan } & \end{array}$

F. Paragog (the addition of sound that occurs at the end of a word)

This can be seen in the following data:

$\begin{array}{cccc}* \text { sa } & > & \text { sai } & \text { 'one' } \\ \text { *laku } & > & \text { lapah } & \text { 'to walk' } \\ & > & \text { lapa:al } & \end{array}$

G. Metathesis (a process of sound change that manifests in the exchange of two phonemes)

This case is very rarely found in Ranau, Krui, and Retta. From the data obtained only one example as shown as follows. 


$\begin{array}{cccc}* \text { tu } & > & \text { Udi } & \text { 'that' } \\ & > & \text { Seno } & \\ \text { *hitem } & > & \text { aGa } & \\ & & \text { Halom } & \text { 'black' } \\ \text { *binatang } & > & \text { binanta } & \text { 'animal' } \\ \text { *cidah } & > & \text { Cutik } & \text { 'little' } \\ & > & \text { Kudik } & \\ \text { *halir } & > & \text { Hili } & \text { 'to flow' } \\ & > & \text { To:tu } & \text { 'to flow' }\end{array}$

\section{CONCLUSION}

Based on the analysis, it can be concluded that Ranau, Krui, and Retta show a number of similarities and differences. From synchronous and diachronic studies, there are individual characteristics or distinctive details, which prove that all three have different developmental histories. A special phonemic correspondence analysis of the primary rules found as follows: phonemic correspondence of proto phoneme */ e / Papua New Guinea has a split which is reflected into two phonemes namely phoneme / o / and / a /. In Ranau and Krui * / e / are reflected into phoneme / o / and in Retta, it is reflected into phoneme / a /. The phoneme correspondence of proto $* / \mathrm{k} /$ Proto Malayo Polynesian has a split which is reflected in two phonemes such as phoneme / h / and / 1/. In Ranau and Krui * / $\mathrm{k} /$ is reflected to / $\mathrm{h} /$ and in Retta is reflected to phoneme / 1 /. Based on observations and reconstructions through cognate devices, it can be argued that proto phonemes of PMP and PNM cause phonemic innovations in Ranau, Krui, and Retta. Phonemes that experienced the phonemic innovation are $* \mathrm{k}$, * $\mathrm{y}, * \mathrm{~d}, * \mathrm{t}, *$ b. $* \mathrm{n}, * \mathrm{~m}$.

\section{REFERENCES}

[1] V. Fromkin, Robert Rodman, and Nina Hyams, An Introduction to Language. Mexico: Wadsworth, 2016.

[2] D. Crystal, Language Death. Cambridge: Cambridge University Press Fromkin, 2000.

[3] A. I wayan, "Arka, I wayan. 2016. Bahasa-bahasa Nusantara: Tipologinya dan Tantangannya bagi Tatabahasa Leksikal-Fungsional https://www.researchgate.net.," 2016. [Online]. Available: https://www.researchgate.net.

[4] A. Schapper, The Papuan Languages of Timor, Alor and Pantar. Volume 1. Mouton: De Gruyter, 2014.

[5] Z. Hidayah, Ensiklopedi Suku Bangsa di Indonesia. Jakarta: Yayasan Obor, 2016.

[6] Marian Klamer, The Alor Pantar Languages History and Typology. Second Edition. Berlin: Language Science Press, 2017.

[7] M. Ross, "Prononouns as preliminary diagnostic for grouping Papuan languages'. Canberra: Pacific Languistics," in In Andrew K. Pawley, Robert Attemborough, Jack Golson and Robin Hide (eds).
Papuan pasts: cultural, linguistic and biological histories of Papua speaking peoples, 15-65., Canberra: Pacific Languistics, 2005.

[8] G. F. Simons and Charles D. Fenning, "Ethnologue: Languages of the World, Twentieth edition. Dallas, Texas: SIL International.," 2017. [Online]. Available: http://www.ethnologue.com.

[9] W. Kurniawati, "Pendokumentasian Bahasa Retta yang Terancam Punah," in dalam Buku Kumpulan Makalah Kongres Internasional Masyarakat Linguistik Indonesia (KIMLI) 2016. "Menggali Kekayaan Bahasa Nusantara,” Denpasar: Universitas Udayana, 2016.

[10] Sudaryanto, Metode Linguistik Bagian Pertama ke Arah Memahami Metode Linguistik. Yogyakarta: Gajah Mada University Press, 1988.

[11] Sudaryanto, Metode dan Aneka Teknik Analisis Bahasa: Pengantar Penelitian Wahana Kebudayaan secara Linguistik. Yogyakarta: Duta Wacana University Prees, 1993.

[12] Abdullah and Darsita Suparno, Kebudayaan Petani Damar Pesisir Pantai Barat Krui Perspsetif Antropologi Linguistik. Jakarta: Laporan Penelitian UIN Syarif Hidayatullah Jakarta, 2013.

[13] Arifin, Siti Salamah, and dkk, Fonologi dan Morfologi Bahasa Ranau. Jakarta: Pusat Pembinaan dan Pengembangan Bahasa Departemen Pendidikan Kebudayaan, 1998.

[14] T. Crowley, An Introduction to Historical Linguistics. Papua: University of Papua New Gueniea Press, 1987.

[15] G. Keraf, Linguistik Bandingan Historis. Jakarta: PT Gramedia, 1984. 